\title{
Gastroesophageal reflux disease and the relationship with Helicobacter pylori
}

\author{
Zeynel Mungan', Binnur Pınarbaşı Şimşek² \\ 'Department of Gastroenterology, Koç University School of Medicine, İstanbul, Turkey \\ ${ }^{2}$ Department of Gastroenterology, İstinye University School of Medicine, İstanbul, Turkey
}

Cite this article as: Mungan Z, Pınarbaşı Şimşek B. Gastroesophageal reflux disease and the relationship with Helicobacter pylori. Turk J

Gastroenterol 2017;28(Suppl 1); S61-S67

\begin{abstract}
After Helicobacter pylori was identified, and its relationship with peptic ulcer disease was exactly shown, the relationship of this bacterium with gastroesophageal reflux disease (GERD) gained momentum and discussions continue to this day. We reviewed the literature for the relationship between $\mathrm{H}$. pylori and GERD. According to the existing data, there is no relationship between GERD and H. pylori presence. Successful eradication therapy does not have an impact on the emergence or exacerbation of GERD. However Barrett's esophagus and esophageal adenocarcinoma are less frequent, especially in the presence of CagA positive H. pylori infections. Longterm use of proton pump inhibitor (PPI) may have an impact on the development of atrophy and/or intestinal metaplasia in H. pylori positive patients; therefore, H. pylori eradication is recommended in patients that should use long-term PPI. As a conclusion, H. pylori screening and the eradication decision should be independent of GERD, except for patients that will use long-term PPI.
\end{abstract}

Keywords: Helicobacter pylori, gastroesophageal reflux disease, proton pump inhibitors, gastric atrophy, esophagus cancer, Barrett esophagus

The effects of the presence of Helicobacter pylori (Hp) and the eradication therapy of Helicobacter pylori on the progress and complications of GERD were examined under four main headings.

\section{DOES THE PRESENCE OF HELICOBACTER PYLORI AFFECT THE PREVALENCE, SYMPTOM SCORES, SEVERITY, AND RELAPSE OF REFLUX?}

Helicobacter pylori infection has been thought to play a facilitating role for the development of GERD by causing a reduction in the lower esophageal sphincter (LES) pressure, an increase in the transient relaxation of the lower esophageal sphincter, hypergastrinaemia, and a delay in gastric emptying. On the other hand, it has been suggested to be protective from GERD because it leads to a reduction in acid secretion and provides acid neutralization due to the gastritis type it creates. With the implementation of eradication therapies, a decrease has occurred in the prevalence of H. pylori; how- ever, the frequency and complications of GERD have increased. This result supports the view that H.pylori may be protective from GERD. In an epidemiological study, the prevalence of H.pylori was reported to be lower in GERD than the non-reflux group (32.8\% vs. $49.5 \%$; OR: 0.58) (1). The first clinical trials showed that the presence of H.pylori reduced the need for proton pump inhibitor (PPI) (2). When compared in terms of maintaining symptomatic and endoscopic remission, H.pylori eradicated ( $H p$ negative, $H p$-) GERD patients were indicated to need a higher dose of PPI than patients that had H.pylori (Hp positive, $\mathrm{Hp+}$ ) (3). Subsequently, it was shown that erosive esophagitis developed more frequent in patients treated with H.pylori eradication compared to Hp+ patients (4). It was reported in another study that reflux esophagitis recovered synchronous in patients who underwent eradication therapy due to peptic ulcers (5). In epidemiological studies, it was seen that there were differences between the East and the 
West; but there was an inverse relationship between H. pylori prevalence and GERD when all the proportions were evaluated together (1).

In order to search for the answers to this controversial question, when the keywords "Gastroesophageal reflux disease [MeSH Terms]" AND "Helicobacter pylori [MeSH Terms]" were entered, a total of 293 studies were found in the systematic literature review written in English on adult subjects. Of these, 17 randomized controlled studies, consistent with the criteria, and 4 meta-analyses (covering also 17 randomized controlled studies) were evaluated. A meta-analysis, by Cremonini et al. (6), that involved 14 case-control studies and 10 clinical trials, analyzed the effect of H.pylori eradication among participants in terms of "de novo" reflux development and progression in the existing symptoms of reflux. It was identified that eradication therapy increased new reflux development 3.25 times $(95 \% \mathrm{Cl}$ , 2.09-5.33), rebound reflux development increased 2.39 times (95\% Cl 1.75-3.34), and new or rebound reflux development increased 2.54 times (95\% Cl 1.92-3.37). Despite this metaanalysis that states the presence of H.pylori is protective against the development of GERD, other studies have not reached this conclusion. In the meta-analysis, by Yaghoobi et al. (7), that involved five cohort studies and 7 randomized controlled trials (RCTs), all H.pyloritand non-GERD patients were compared by receiving placebo vs. eradication therapy in terms of new reflux symptoms and/or reflux esophagitis development. Cohort studies and RCTs were assessed separately; the odds ratio was found as 1.22 (95\% Cl 0.89-1.69) for the risk of symptomatic GERD development in RCTs, 1.11 (95\% Cl 0.81-1.53) for the risk of erosive esophagitis development, and $1.37(95 \% \mathrm{Cl} 0.89$ 2.12) for the risk of GERD development in cohort studies (7). In another meta-analysis, 11 RCTs were evaluated. GERD and nonGERD groups were initially included in this study; the group in which eradication was applied and H.pylori persistent groups were examined in terms of the development of symptomatic reflux and/or erosive esophagitis. As a result, no difference was detected between the two groups in terms of symptomatic reflux, heartburn, and erosive esophagitis frequency. They were indicated as odds ratio: 0.88 (95\% Cl 0.63-1.23), $0.79(95 \% \mathrm{Cl}$ 0.54-1.15), and 0.97 (95\% Cl 0.67-1.40), respectively (8). Finally, in the meta-analysis by Saad et al. (9) of 10 RCTs, the group of $\mathrm{Hp}$ therapy vs. placebo and the group in which a successful $\mathrm{Hp}$ was applied vs. persistent group were compared among themselves in terms of the development of symptomatic reflux and erosive esophagitis, and similar conclusions were reached: The odds ratio was found as 0.81 ( $95 \% \mathrm{Cl} 0.56-1.71)$ for the development of symptomatic reflux and as 1.13 (95\% Cl 0.72-1.78) for the development of erosive esophagitis. Moreover, a decrease in the rate of symptomatic reflux was found in the group with successful $\mathrm{Hp}$ eradication in comparison to the persistent group (13.8\% vs. 24.9\%; OR: 0.55; 95\% Cl 0.35-0.87) (9). When

Table 1. The relationship between H. pylori eradication therapy and the development of symptomatic reflux disease and erosive esophagitis

\begin{tabular}{lll}
\hline Author/Journal/Year & Study Design & Comparison Groups \\
\hline Cremonini et al. (6), & Meta-analysis & ${ }^{* H p E ~ t x+v s . ~ t x-~}$ \\
Aliment Pharmacol & (14 case control & *Successful HpE tx vs. HpP \\
Ther, 2003 & 10 RCT) & *before HpE tx vs. after \\
& & HpE tx
\end{tabular}

Endoscopic

esophagitis and reflux symptoms HpE tx

Yaghoobi et al. (7), Am J Gastroenterol, 2010

\begin{abstract}
Meta-analysis (5 cohort study $7 \mathrm{RCT})$
\end{abstract}

All cases $\mathrm{Hp}+$ and
GERD(-)
HpE tx vs. Placebo

Erosive esophagitis or reflux symptoms
Denovo reflux symptoms or the development of reflux esophagitis
Quian et al. (8), Helicobacter, 2011
Meta-analysis (11 RCT)
Baseline patients with and without GERD HpE txvs. HpP
Symptomatic reflux disease, erosive esophagitis
Development or progression denovo and recurrent reflux disease
Saad et al. (9), Meta-analysis

Scand J Gastroenterol, (10T) 2012

\author{
-HpE tx vs placebo \\ -Successful HpE tx vs. \\ unsuccessful HpE tx \\ Symptomatic reflux \\ disease, erosive \\ esophagitis
}

\section{Results (OR) \\ Denovo: 3.25 \\ (95\% Cl 2.09-5.33) \\ Rebaund: 2.39 \\ (95\% Cl 1.75-3.34) \\ Denovo + Rebaund: 2.54 \\ (95\% Cl 1.92-3.37)}

Symptomatic GERD for

RCT: 1.22 (95\% Cl 0.89-1.69)

Endoscopic GERD for

RCT: 1.11 (95\% Cl 0.81-1.53)

GERD for cohort study:

1.37 (95\% Cl 0.89-2.12)

Incidence of symptomatic reflux: 0.88 (95\% Cl 0.63-1.23) Incidence of heartburn: 0.79 (95\% Cl 0.54-1.15) Incidence of erosive esophagitis: 0.97 (95\% Cl 0.67-1.40)

\section{Development of} symptomatic reflux: 0.81 (95\% Cl 0.56-1.71)

Development of erosive esophagitis: 1.13

$(95 \% \mathrm{Cl} 0.72-1.78)$ 
Table 2. The comparison between the group with successful H. pylori eradication therapy and persistent groups in terms of symptomatic reflux disease and erosive esophagitis incidence

\begin{tabular}{|c|c|c|c|c|c|c|c|}
\hline META-ANALYSIS & & & & OR $(95 \% \mathrm{CI})$ & & & \\
\hline & incidence of & incidence of & incidence of & incidence of & Incide & ce of GERD according to & o disease \\
\hline Author/Publication date & symptomatic & hearthburn & reflux esophagitis & endoscopic esophagitis & Peptic Ulcer & Functional Dyspepsia & GERD \\
\hline Yaghoobi et al. (7) 2010 & $1.22^{*}(0.88-1.69$ & & & $1.17(0.89-2.12)$ & $1.26^{*}(0.88-1.80)$ & $0.61 *(0.28-1.32)$ & \\
\hline & & & & & $2.04^{* *}(1.88-3.85)$ & $0.84^{* *}(0.44-1.58)$ & \\
\hline Cremonini et al. (6) 2003 & $1.34(1.15-1.55)$ & & & & $1.79(1.26-2.54)$ & $2.28(1.52-3.45)$ & \\
\hline
\end{tabular}

*data of RCT ${ }^{* *}$ data of cohort study

a subgroup analysis was made in these four meta-analyses in terms of the disease groups in which Hp eradication was performed, the rate of GERD development after $\mathrm{Hp}$ eradication was found higher in the group that was given eradication therapy due to peptic ulcers than the group that was given eradication therapy due to functional dyspepsia $(6,7)$ [In the study of Yaghoobi et al. (7), OR: 1.26, 95\% Cl 0.88-1.80 for RCT and OR: $2.04,95 \% \mathrm{Cl} 1.88-3.85$ for cohort studies and in the study of Cremonini et al. (6) OR: 1.79; 95\% Cl 1.26-2.54] was detected.]

According to the existing data, there is no relationship between GERD and $H$. pylori presence. Successful eradication therapy does not have an impact on the emergence or exacerbation of GERD. However, the development of GERD after eradication can be considered in patients with peptic ulcers. All the data of the above-mentioned studies are summarized in Table 1 and Table 2.

\section{DOES THE RISK OF ATROPHIC GASTRITIS INCREASE IN THE PRESENCE OF HELICOBACTER PYLORI IN GERD PATIENTS USING LONG-TERM PPI? DOES HELICOBACTER PYLORI ERADICATION AFFECT THE RISK IN THESE PATIENTS?}

Proton pump inhibitor (PPI) treatment alters the distribution of H.pylori in the stomach and causes corpus-fundus dominant gastritis with decrease in gastric acid secretion. While the annual development of atrophy was $10.9 \%$ in H.pylori + patients using PPI, this rate was found $0.9 \%$ in H.pylori - patients (10). In another study including patients not using a PPI, while this rate was $1.8 \%$ in H.pylori + cases, it was found $0.3 \%$ in H.pylori - cases (11). A search was made by entering the keywords "proton pump inhibitors [MeSH Terms]" AND "atrophic gastritis [MeSH Terms]" OR "Helicobacter pylori [MeSH Terms]" in the PubMed search, and a total of 7 RCTs were found qualified enough to answer the question above. While the groups that were taking PPI and underwent anti-reflux surgery (ARS) were compared in three of these studies, the groups in which H.pylori eradication was and was not received were compared in the others. In the RCT of Kuipers et al. (12), PPI therapy was given to 105 patients with GERD and ARS was applied in 72 patients. At the end of the 84-month follow-up, while the rate of atrophic gastritis development for H.pylori+ cases was 31\% in the omeprazole arm, it was found 3\% in the ARS arm. In H.pylori- cases, whereas the same rate was 4\% in those using omeprazole, it was found to be $0 \%$ in the ARS arm. In the study of Lundell et al. (13), 155 patients in whom GERD was proven endoscopically were given omeprazole and ARS was applied in 155 patients. At the end of a 36-month followup, a mild progression was seen in glandular corpus atrophy in H.pylori+patients, and similar results were observed in the two arms in term of intestinal metaplasia. In the study of Lundell et al. (14) in 2006, omeprazole was administered in 98 of a total of 215 GERD patients, and ARS was applied in 117. It was shown that glandular atrophy developed in 5 of the $13 \mathrm{H}$.pylori+patients using omeprazole and in 3 of the 12 patients who underwent ARS at the end of a 84-month follow-up. In the prospective randomized case-control study of Schenk et al. (15), 57 H.pylori+and 26 H.pylori - GERD patients receiving omeprazole vs. placebo were followed for 12 months after eradication therapy; the rate of atrophy in corpus was observed not to have changed in the eradication arm. In another prospective double-blind RCT, omeprazole vs. placebo treatment was given to patients with 15 GERD with Hp+ omeprazole vs. eradication therapy was applied to another patients with 15 GERD with $\mathrm{Hp}+$, and patients with 11 GERD without $H p$ were received placebo as a control group. Whereas a slight atrophy in corpus occurred in 5 of the 11 patients who completed a one-year follow-up in the omeprazole arm, atrophy was seen in none of the 8 patients to whom eradication therapy was given ( $p=0.02)$ (16). In the RCT of Kuipers et al. (17) involving 231 H.pylori + GERD patients, omeprazole was given to 120 patients and H.pylori eradication therapy was applied to 111 patients; maintenance therapy was provided with omeprazole for 24 months. Atrophy in corpus was observed to regress in the eradication arm compared to the H.pylori + omeprazole arm ( $p=0.001)$, and no change occurred in intestinal metaplasia. In the study by Yang et al. (18), which involved 325 GERD patients (105 H.pylori + were given eradication treatment, 105 H.pylori + were followed without treatment, and 115 H.pylori - were in the control group) who were followed up24-month period after eradication therapy or placebo, the prevalence of atrophic gastritis was found to be $5.4 \%$ in the H.pylori eradication arm, $15.7 \%$ in the arm without treatment, and $0 \%$ in the control group. Intestinal metaplasia was reported as $19.4 \%$ in eradica- 
Table 3. The application of eradication therapy can prevent the development and progression of gastric atrophy and intestinal metaplasia

\begin{tabular}{|c|c|c|c|c|c|c|c|}
\hline $\begin{array}{l}\text { Author/ } \\
\text { Publication date }\end{array}$ & $\begin{array}{l}\text { Study } \\
\text { Design }\end{array}$ & $\begin{array}{l}\text { Group of } \\
\text { Patient }\end{array}$ & $\begin{array}{l}\text { Methods of } \\
\text { Treatment }\end{array}$ & $\mathrm{Hp}+/-$ & $\begin{array}{l}\text { Fw-up period } \\
\text { (month) }\end{array}$ & $\begin{array}{l}\text { Results } \\
\text { AG / IM }\end{array}$ & $\begin{array}{l}\text { Corpus } \\
\text { Gastritis }\end{array}$ \\
\hline $\begin{array}{l}\text { Kuipers et al. (12) } \\
\text { NEJM, } 1996\end{array}$ & $\mathrm{RCT}$ & GERD & $\begin{array}{l}105 \text { OMP } \\
72 \text { ARS }\end{array}$ & $\begin{array}{l}\text { OMP 59/105 } \\
\text { ARS 31/72 }\end{array}$ & 84 & $\begin{array}{l}\text { rate of AG for Hp + group } \\
\text { - OMP } 31 \%(18 / 59) \\
\text { - ARS } 3 \%(1 / 31) \\
\text { rate of AG for Hp - group } \\
\text { - OMP } 4 \%(2 / 46) \\
\text { - ARS 0\% }\end{array}$ & Increased \\
\hline $\begin{array}{l}\text { Schenk et al. (15) } \\
\text { Gut, } 2000\end{array}$ & $\begin{array}{l}\text { RCT } \\
\text { prospective } \\
\text { randomized } \\
\text { case control }\end{array}$ & $\begin{array}{l}\text { GERD } \\
57 \mathrm{Hp}+ \\
26 \mathrm{Hp}-\end{array}$ & $\begin{array}{l}\text { HpE vs. Hp placebo } \\
\text { followed by } \\
\text { maintenance with } \\
\text { OMP }\end{array}$ & $\begin{array}{l}\mathrm{Hp}+/+: 24 \\
\mathrm{Hp}+/-: 33 \\
\mathrm{Hp}-: 26\end{array}$ & 12 & $\begin{array}{l}\text { Decreased in antral atrophy in } \\
\text { HpE tx group but no change } \\
\text { corpus atrophy }\end{array}$ & Increased \\
\hline $\begin{array}{l}\text { Kuipers et al. (17) } \\
\text { Gut, } 2004\end{array}$ & $\mathrm{RCT}$ & $\begin{array}{l}231 \mathrm{Hp}+ \\
\text { GERD } \\
120 \mathrm{OMP} \\
\text { vs. } 111 \mathrm{HpE} \\
\text { No control Hp- }\end{array}$ & $\begin{array}{l}\text { Maintenance } \\
\text { theraphy with } \\
\text { OMP } \\
\text { for } 2 \text { years } \\
\text { - }\end{array}$ & & 24 & $\begin{array}{l}\mathrm{HpE} \text { vs } \mathrm{Hp}+\mathrm{OMP} \\
\text { rate of antral IM and AG: no change } \\
\text { rate of corpus atrophy: decrease }(\mathrm{p}=0.001) \\
\text { rate of } \mathrm{IM} \text { in corpus: no change }\end{array}$ & Increased \\
\hline $\begin{array}{l}\text { Lundell et al. (14) } \\
\text { APT } 2006\end{array}$ & $\mathrm{RCT}$ & $\begin{array}{l}215 \\
\text { GERD }\end{array}$ & $\begin{array}{l}98 \text { OMP } \\
117 \text { ARS }\end{array}$ & $\begin{array}{l}\text { OMP 39/98 } \\
\text { ARS 53/117 }\end{array}$ & 84 & $\begin{array}{l}\text { Number of patients }(\mathrm{Hp}+) \\
\text { completed follow-up } \\
\text { OMP: } 13 \\
\text { ARS: } 12 \\
\text { Glandulary atrophy: } 5 / 13 \text { vs 3/12 }\end{array}$ & Increased \\
\hline
\end{tabular}

OMP: omeprazo; ARS: anti-reflux surgey; HpE: H. pylori eradication theraphy; IM: intestinal metaplasia AG: atrophic gastritis

tion arm, as $36.2 \%$ in the arm without treatment, and as $2 \%$ in H.pylori - control arm. In all studies, an increase in corpus gastritis was observed in the H.pylori+ groups using long-term PPI.

In light of this data, long-term use of PPI therapy in H.pylori + patients can lead to the development of corpus predominant gastritis. The application of eradication therapy can prevent the development and progression of gastric atrophy and intestinal metaplasia (Table 3).

\section{DOES THE PRESENCE OF HELICOBACTER PYLORI AFFECT THE FREQUENCY OF BARRETT'S ESOPHAGUS (WITH OR WITHOUT DYSPLASIA)?}

The incidence of esophageal adenocarcinoma has been increasing gradually in developed countries over the last three decades. Barrett's esophagus (BE) is a precancerous lesion for esophageal adenocarcinoma and the incidence is $<2 \%$ in the general population (19). The relationship between H.pylori and BE development seems somewhat complicated. In the literature, there are studies that reach different results on this issue; in addition to the studies reporting that the presence of H.pylori is a risk factor for BE development, there are studies reporting that it does not influence the development of BE or it prevents BE development (20-29). In the study by Vaezi et al. (29), it was found that being infected with H.pylori had a protective effect for development of BE and its malignant complications. This effect was more apparent in the infection with the CagA+ (positive) strain. In the study by Thrift et al. (30), the risk of BE development was reported to be lower, $80 \%$ in H. pylori+GERD patients in comparison to H.pylori - reflux patients (OR: 2.6 vs. 8.24) (30). 
Table 4. The presence of $\mathrm{Hp}$ seems to be protective from BE development and the protective effect is more evident in CagA+ patients

\begin{tabular}{|c|c|c|c|c|c|}
\hline Author/Publication date & Study design & Comparison groups & "Outcome measure" & Results & Results (RR/OR) \\
\hline
\end{tabular}

BE: Barret esophagus

Table 5. The presence of $\mathrm{Hp}$, and especially the infection with the CagA+ strain, show a protective effect against esophageal adenocarcinoma. The relationship between $\mathrm{Hp}$ and esophagus squamous cell cancer is not clear

\begin{tabular}{|c|c|c|c|c|c|}
\hline Author/Publication date & Study design & Comparison groups & Outcome measure & Results & Results (RR /OR) \\
\hline $\begin{array}{l}\text { Islami et al. (35) } \\
\text { Cancer Rev Pres } 2008\end{array}$ & $\begin{array}{l}\text { Meta-analysis } \\
\text { (19 study) } \\
\text { Adeno Ca: } 13 \text { study: } \\
848 \text { patients/2890 } \\
\text { control group } \\
\text { Squamous Ca: } \\
9 \text { study: } \\
921 \text { patients/2743 } \\
\text { control group }\end{array}$ & $\begin{array}{l}\text { Hp+ vs. Hp- } \\
\text { cagA+ vs. cagA- }\end{array}$ & $\begin{array}{l}\text { Risk of Adeno Ca } \\
\text { or } \\
\text { Squamous Ca }\end{array}$ & $\begin{array}{l}\text { H. pylori reduces the } \\
\text { risk Adeno } \\
\mathrm{Ca} \text {, this phenomenon more } \\
\text { pronounced rate in cagA + } \\
\text { Hp does not affect the risk of } \\
\text { squamous Ca. No relationship } \\
\text { with the cagA. }\end{array}$ & $\begin{array}{l}\text { ADENO CA } \\
\text { Overall OR: } 0.56 \\
\text { (95\% Cl 0.46 -0.68) } \\
\text { cagA+ OR: } 0.41 \\
\text { (95\% Cl 0.28-0.62) } \\
\text { cagA- OR: } 1.08 \\
\text { (95\% Cl 0.76-1.53 } \\
\text { SQUAMOUS CA } \\
\text { Overall OR: } 1.1 \\
\text { (95\% Cl 0.78-1.55) } \\
\text { cagA+ OR: } 1.01 \\
\text { (95\% Cl 0.80-1.27) } \\
\text { cagA- OR: } 1 . .41 \\
\text { (95\% Cl 1-1.97) }\end{array}$ \\
\hline
\end{tabular}

In order to examine the subject, a search was made using the keywords "Barrett esophagus [MeSH Terms]" AND "Helicobacter pylori [MeSH Terms]" and a total of 176 trials were found. Two meta-analyzes among them were included in the evaluation. In the research of Fischbach et al. (31), 44 case-control studies and 5 cross-sectional studies were included in the evaluation. Whether the H.pylori prevalence in patients with Barrett's esophagus and protective effect of being infected with the CagA+ strain for BE was investigated. The presence of H.pylori was shown to be protective for BE development (RR: $0.73,95 \%$ $\mathrm{Cl}$ 0.60-0.88) and this effect was higher in patients infected with the CagA+ strain (RR: $0.38,95 \% \mathrm{Cl} 0.19-0.78)$. In the meta-analysis of Wang et al. (32), 12 case-control studies were evaluated. 550 BE patients were compared with 2979 volunteers consisting of healthy blood donors with normal endoscopic examination. While the H.pylori prevalence was $42.9 \%(236 / 550)$ in the group of Barrett's esophagus while it was found to be $43.9 \%$ (1308/2979) in healthy volunteers (OR: 0.74, 95\% Cl 0.40-1.37).

According to the available data, the presence of H.pylori seems to be protective for $\mathrm{BE}$ development and this effect is more evident in CagA+ patients. This data is summarized in Table 4. 


\section{DOES THE PRESENCE OF HELICOBACTER PYLORI AFFECT THE INCIDENCE OF ESOPHAGEAL CANCER?}

The persistent H.pylori infection in GERD has been reported to be a risk factor for a subtype of esophageal squamous cell carcinoma (33). On the other hand, it has been suggested that the presence of H.pylori protects from the development of esophageal adenocarcinoma through various mechanisms (hypoacidity, decrease in gastric ghrelin secretion, affected gastric and esophageal microbiota, and it leads to changes in gastric T-cell compartments) (34). In the search that was conducted to investigate this issue, the keywords "esophagus cancer [MeSHTerms]" AND "Helicobacter pylori [MeSH Terms]" were used and of a total of 142 studies that were obtained. Two meta-analyses meeting the criteria were included in the assessment. The first meta-analysis was published in 2008 and it consisted of 19 studies. The majority of them were community-based and large-scale case-control studies; 13 of them include adenocarcinoma patients (848 patients/2890 control) and 9 of them include squamous cell carcinoma patients (921 patients/2743 control). The patients and controls in this study were grouped in term of $\mathrm{Hp}$ positivity and $\mathrm{Hp}+$ patients were also grouped in terms of CagA+/CagA- strains. It was shown that H.pylori positivity reduced the risk of adenocarcinoma [overall OR: 0.56 (95\% Cl 0.46-0.68)] and the protective effect was more evident in CagA+ cases [CagA+OR: 0.41 (95\% Cl 0.28-0.62) and CagA- OR: 1.08 (95\% Cl 0.76-1.53)]. However, the presence of H.pylori does not affect the risk of squamous cell carcinoma [Overall OR: 1.1 (95\% Cl 0.78-1.55)]. Similarly, it has also been found that being infected with CagA+ or CagA- strains does not have an association with the development of squamous cell carcinoma [overall OR: 1.1 (95\% Cl $0.78-1.55)]$ (35). In the meta-analysis by Xie et al. (36), a total of 27 community and hospital based studies (15 studies with adenocarcinoma and 16 with squamous cell carcinoma) were assessed. In this study as well, the relationship between the development of cancer in the esophagus and H.pylori was examined, and it was shown that H.pylori positivity reduced the risk of adenocarcinoma development [overall OR: 0.59 (95\% Cl 0.51-0.68)]. While the rate of H.pylori positivity was $35.96 \%(479 / 1332)$ in the group of adenocarcinoma, it was $44 \%(2070 / 4705)$ in the control group. Similar to the aforementioned meta-analysis, it was determined that the presence of H.pylori did not usually affect the risk of squamous cell carcinoma [Overall OR: 0.83 (95\% Cl 0.63-1.03)] and being infected with the CagA+ strain was shown in Eastern studies to reduce the risk of squamous cell carcinoma development more than in Western studies: Eastern CagA+OR: 0.77 (95\% Cl 0.65-0.92) and Western cagA+OR: 1.26 (95\% Cl 0.97-1.63).

In the light of the data presented, the presence of H.pylori, and especially the infection with the CagA+ strain, show a protective effect against esophageal adenocarcinoma. The relationship between $\mathrm{H}$. pylori and esophagus squamous cell cancer is not clear. The data is summarized in Table 5.

\section{RECOMMENDATIONS}

- There is no relationship between H. pylori and GERD (Level of evidence: 1a).

- H. pylori eradication does not have any effects in the emergence or exacerbation of GERD, except for patients with peptic ulcers (Level of evidence: 1a).

- Long-term use of PPI may have an impact on the development of atrophy and/or intestinal metaplasia in H. pylori positive patients; therefore, H. pylori eradication is recommended in patients that should use longterm PPI (Level of evidence: 1b).

- Barrett's esophagus and esophageal adenocarcinoma are less frequent, especially in the presence of CagA positive H. pylori infections (Level of evidence: $3 a$ ).

- H. pylori screening and the eradication decision should be independent of GERD, except for patients that will use long-term PPI (Level of evidence: 5).

Conflict of Interest: No conflict of interest was declared by the authors.

\section{REFERENCES}

1. Raghunath A, Hungin AP, Wooff D, Childs S. Prevalence of Helicobacter pylori in patients with gastro-oesophageal reflux disease: systematic review. BMJ 2003; 5; 326: 737.

2. Hallerbäck B, Unge P, Carling L, et al. Omeprazole or ranitidine in longterm treatment of reflux esophagitis. The Scandinavian Clinics for United Research Group. Gastroenterology 1994; 107: 1305-11. [CrossRef]

3. Schenk BE, Kuipers EJ, Klinkenberg-Knol EC, Eskes SA, Meuwissen SG. Helicobacter pylori and the efficacy of omeprazole therapy for gastroesophageal reflux disease. Am J Gastroenterol 1999; 94: 884-7. [CrossRef]

4. Labenz J, Blum AL, Bayerdörffer E, Meining A, Stolte M, Börsch G. Curing Helicobacter pylori infection in patients with duodenal ulcer may provoke reflux esophagitis. Gastroenterology 1997; 112: 1442-7. [CrossRef]

5. O'Connor HJ, McGee C, Ghabash NM, Cunnane K. Prevalence of gastro-oesophageal reflux disease (GORD) in H.pylori positive peptic ulcer disease and the impact of eradication therapy. Hepatogastroenterology 2001; 48: 1064-8.

6. Cremonini F, Di Caro S, Delgado-Aros S, et al. Meta-analysis: the relationship between Helicobacter pylori infection and gastrooesophageal reflux disease. Aliment Pharmacol Ther 2003; 18: 279-89. [CrossRef]

7. Yaghoobi M, Farrokhyar F, Yuan $\mathrm{Y}$, Hunt RH. Is there an increased risk of GERD after Helicobacter pylori eradication?: a meta-analysis. Am J Gastroenterol 2010; 105: 1007-13.[CrossRef]

8. Qian B, Ma S, Shang L, Qian J, Zhang G. Effects of Helicobacter pylori eradication on gastroesophageal reflux disease. Helicobacter 2011; 16: 255-65. [CrossRef]

9. Saad AM, Choudhary A, Bechtold ML. Effect of Helicobacter pylori treatment on gastroesophageal reflux disease (GERD): meta-analysis of randomized controlled trials. Scand J Gastroenterol 2012; 47: 129-35. [CrossRef]

10. Eissele R, Brunner G, Simon B, Solcia E, Arnold R. Gastric mucosa during treatment with lansoprazole: Helicobacter pylori is a risk factor for argyrophil cell hyperplasia. Gastroenterology 1997; 112: 707-17. [CrossRef] 
11. Kuipers EJ, Uyterlinde AM, Pe-a AS, et al. Long-term sequelae of Helicobacter pylori gastritis. Lancet 1995; 345: 1525-8. [CrossRef]

12. Kuipers EJ, Lundell L, Klinkenberg-Knol EC, et al. Atrophic gastritis and Helicobacter pylori infection in patients with reflux esophagitis treated with omeprazole or fundoplication. N Engl J Med 1996; 334: 1018-22. [CrossRef]

13. Lundell L, Miettinen P, Myrvold HE, et al. Lack of effect of acid suppression therapy on gastric atrophy. Nordic Gerd Study Group. Gastroenterology 1999; 117: 319-26. [CrossRef]

14. Lundell L, Havu N, Miettinen P, et al. Changes of gastric mucosal architecture during long-term omeprazole therapy: results of a randomized clinical trial. Aliment Pharmacol Ther 2006; 23: 639-47. [CrossRef]

15. Schenk BE, Kuipers EJ, Nelis GF, et al. Effect of Helicobacter pylori eradication on chronic gastritis during omeprazole therapy. Gut 2000; 46: 615-21. [CrossRef]

16. Moayyedi P, Wason C, Peacock R, et al. Changing patterns of Helicobacter pylori gastritis in long-standing acid suppression. Helicobacter 2000; 5: 206-14. [CrossRef]

17. Kuipers EJ, Nelis GF, Klinkenberg-Knol EC, et al. Cure of Helicobacter pylori infection in patients with reflux oesophagitis treated with long term omeprazole reverses gastritis without exacerbation of reflux disease: results of a randomised controlled trial. Gut 2004; 53: 12-20. [CrossRef]

18. Yang HB, Sheu BS, Wang ST, Cheng HC, Chang WL, Chen WY. H. pylori eradication prevents the progression of gastric intestinal metaplasia in reflux esophagitis patients using long-term esomeprazole. Am J Gastroenterol 2009; 104: 1642-9. [CrossRef]

19. El-Serag HB, Mason AC, Petersen N, Key CR. Epidemiological differences between adenocarcinoma of the oesophagus and adenocarcinoma of the gastric cardia in the USA. Gut 2002; 50: 368-72. [CrossRef]

20. Henihan RD, Stuart RC, Nolan N, Gorey TF, Hennessy TP, O'Morain CA. Barrett's esophagus and the presence of Helicobacter pylori. Am J Gastroenterol 1998; 93: 542-6. [CrossRef]

21. Loffeld RJ, Ten Tije BJ, Arends JW. Prevalence and significance of Helicobacter pylori in patients with Barrett's esophagus. Am J Gastroenterol 1992; 87: 1598-600.

22. Meng X, Scheer MA, Tsang TK. GERD: Barrett's esophagus and Helicobacter pylori infection. Gastroenterology 2008; 134: A443. [CrossRef]

23. Csendes A, Smok G, Cerda G, Burdiles P, Mazza D, Csendes P. Prevalence of Helicobacter pylori infection in 190 control subjects and in 236 patients with gastroesophageal reflux, erosive esophagitis or Barrett's esophagus. Dis Esophagus 1997; 10: 38-42. [CrossRef]

24. Peng S, Cui Y, Xiao YL, et al. Prevalence of erosive esophagitis and Barrett's esophagus in the adult Chinese population. Endoscopy 2009; 41: 1011-7. [CrossRef]

25. Corley DA, Kubo A, Levin TR, et al. Helicobacter pylori infection and the risk of Barrett's oesophagus: a community-based study. Gut 2008; 57: 727-33. [CrossRef]

26. Fassan M, Rugge M, Parente P, Tieppo C, Rugge M, Battaglia G. The role of Helicobacter pylori in the spectrum of Barrett's carcinogenesis. Cancer Prev Res (Phila) 2009; 2: 94. [CrossRef]

27. Sonnenberg A, Lash RH, Genta RM. A national study of Helicobactor pylori infection in gastric biopsy specimens. Gastroenterology 2010; 139: 1894-1901. [CrossRef]

28. Vieth M, Masoud B, Meining A, Stolte M. Helicobacter pylori infection: protection against Barrett's mucosa and neoplasia? Digestion 2000; 62: 225-31. [CrossRef]

29. Vaezi MF, Falk GW, Peek RM, et al. cagA-positive strains of Helicobacter pylori may protect against Barrett's esophagus. Am J Gastroenterol 2000; 95: 2206-11. [CrossRef]

30. Thrift AP, Kramer JR, Qureshi Z, Richardson PA, El-Serag HB. Age at onset of GERD symptoms predicts risk of Barrett's esophagus. Am J Gastroenterol 2013; 108: 915-22. [CrossRef]

31. Fischbach LA, Nordenstedt $H$, Kramer JR, et al. The association between Barrett's esophagus and Helicobacter pylori infection: a meta-analysis. Helicobacter 2012; 17: 163-75. [CrossRef]

32. Wang C, Yuan Y, Hunt RH. Helicobacter pylori infection and Barrett's esophagus: a systematic review and meta-analysis. Am J Gastroenterol 2009; 104: 492-500. [CrossRef]

33. Ye W, Held M, Lagergren J, et al. Helicobacter pylori infection and gastric atrophy: risk of adenocarcinoma and squamous-cell carcinoma of the esophagus and adenocarcinoma of the gastric cardia. J Natl Cancer Inst 2004; 96: 387-96. [CrossRef]

34. Blaser MJ. Disappearing microbiota: Helicobacter pylori protection against esophageal adenocarcinoma. Cancer Prev Res (Phila) 2008; 1: 308-11. [CrossRef]

35. Islami F, Kamangar F. Helicobacter pylori and esophageal cancer risk: a meta-analysis. Cancer Prev Res (Phila) 2008; 1: 329-38. [CrossRef]

36. Xie FJ, Zhang YP, Zheng QQ, et al. Helicobacter pylori infection and esophageal cancer risk: an updated meta-analysis. World J Gastroenterol 2013; 19: 6098-107. [CrossRef] 